Reprod. Nutr. Dévelop. 1980, 20 (4 A), 1101-1109.

\title{
The control of male fertility by 6-chloro-6-deoxysugars
}

\author{
par W. C. L. FORD, G. M. H. WAITES
}

Department of Physiology and Biochemistry, The University, Whiteknights, Reading RG6 2AJ, U. K.

\section{Summary.}

1. 6-Chloro-6-deoxyglucose $(24 \mathrm{mg} / \mathrm{kg} /$ day) produces a rapid and reversible antifertility effect in the male rat but high doses ( $>200 \mathrm{mg} / \mathrm{kg} /$ day) produce spermatocoeles. In the mouse repeated high doses $(480 \mathrm{mg} / \mathrm{kg} / \mathrm{day})$ cause paralysis of the hind limbs but there is no effect on fertility.

2. Spermatozoa from rats treated with 6-chloro-6-deoxyglucose $(24 \mathrm{mg} / \mathrm{kg} /$ day) are unable to metabolize glucose and rapidly become exhausted when glucose is the only substrate supplied. Glycolysis is inhibited at the glyceraldehyde 3-phosphate dehydrogenase reaction. These spermatozoa can obtain energy by oxidizing pyruvate or lactate.

3. The side effects prevent the use of 6-chloro-6-deoxyglucose by humans but a fuller understanding of their mode of action may lead to the development of compounds with a more selective attack on spermatozoa.

\section{Introduction.}

The feasibility of a male contraceptive depends on the existence of features peculiar to the male reproductive system which render it susceptible to selective attack. A majority of the methods which have been proposed seek to inhibit spermatogenesis in order to induce azoospermia (see Hutchinson and Poulson, 1977 ; Ewing and Robhaire, 1978).

However a better approach may be to attack spermatozoa stored in the cauda epididymidis. The epididymis can concentrate a number of compounds, e. $g$. carnitine and glycerylphosphorylcholine (Brooks ef al., 1974) and a drug might be accumulated by these mechanisms. Spermatozoa contain special isoenzymes of lactate dehydrogenase (Clausen, 1969) and hexokinase (Katzen, 1967) and exhibit unusual biochemical features, e. g. the accumulation of acetyl carnitine (Casillas and Erickson, 1975). Spermatozoa also have unusual structural features, e. g. they are haploid, flagellated, free living cells with a unique organelle, the acrosome, and unusual mitochondria (see Philips, 1975). Therefore it should be possible to discover compounds with the appropriate «selective toxicity 》 (Albert, 1973). Such a drug would have a rapid action because there would be no need to clear the fertile spermatozoa which remained in the epididymis. It would be unlikely to cause mutagenesis or to have detrimental effects on libido. 
$\alpha$-Chlorohydrin (3-chloropropan-1,2-diol) produces a rapid and reversible antifertility effect in male animals of several species including the rat by attacking spermatozoa stored in the cauda epididymidis (see Kalla, 1976 ; Jones, 1978). However this compound is not acceptable for development as a contraceptive for human use.

A number of 6-chloro-6-deoxysugars have an antifertility effect in male rats similar to that of $\alpha$-chlorohydrin (Ford and Waites, 1978a, $b$; Heiffield et al., 1979 ; Ford, 1980). 6-Chloro-6-deoxyglucose (6 CDG) is also active in the marmoset monkey (Hearn, 1978). The $L D_{50}$ for $6 C D G$ in the rat is $>16 \mathrm{~g} / \mathrm{kg}$ whereas the $L D_{50}$ for $\alpha$-chlorohydrin is between $55 \mathrm{mg} / \mathrm{kg}$ (Paul ef al., 1974) and $150 \mathrm{mg} / \mathrm{kg}$ (Jackson et al., 1977) (although the pure $\mathrm{S}(+)$ enantiomer was not toxic at the latter dose). In view of this the antifertility activity of 6-chloro-6-deoxyglucose was investigated in greater detail.

\section{Materials and methods.}

6-Chloro-6-deoxyglucose (6 CDG) was synthesized and generously donated by Drs. E. B. Rathbone and P. J. Simpson, Philip Lyle Memorial Research Laboratory, Tate and Lyle Ltd., Reading, Berks RG6 2BX, U.K. It had a sharp melting point $\left(130-132^{\circ} \mathrm{C}\right)$ and was free from discolouration and inorganic chlorides. The $\mathrm{pH}$ of a $10 \mathrm{p} .100 \mathrm{w} / \mathrm{v}$ solution was neutral and it appeared $>95$ p. 100 pure by g. I. c. (Sweeley ef al., 1963) or t. I. c. (Chloroform : Methanol, $2: 1$ or Ethanol : Ethyl Acetate : Water, $5: 45: 1: 250 \mu \mathrm{m}$ Merck Silica Gel G). D- $\left[\mathrm{U}-{ }^{14} \mathrm{C}\right]$ glucose was obtained from the Radiochemical Centre, Amersham, Bucks. HP7 9LL, U.K. Enzymes and biochemicals were purchased from the Boehringer Corp., Lewes BN7 1LG, U.K. or Sigma Chemical Co. Ltd., Poole, Dorset, BH17 7NH, U.K. CD rats were obtained from Charles River U.K. Ltd., Margate, Kent CT9 4LT, U.K. Experimental procedures are outlined in the figure legends.

\section{Results and discussion.}

The antifertility effect.

In one experiment 6 CDG $(24 \mathrm{mg} / \mathrm{kg} /$ day $)$ was sufficient to have a complete contraceptive effect but in the second a significant number of embryos were sired by males given this dose (fig. 1). Thus larger doses would be required to obtain reliable contraception in highly variable natural populations.

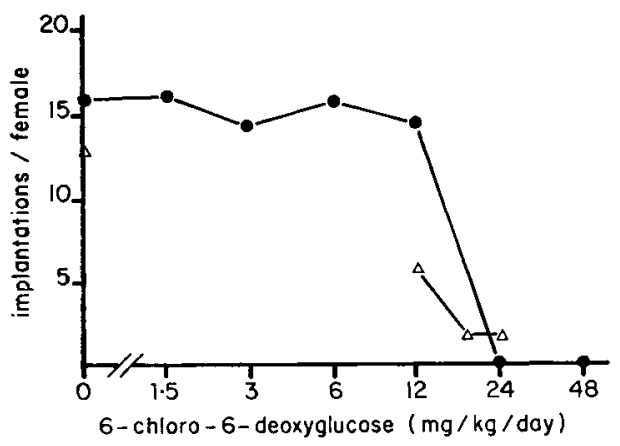

FIG. 1. - The results of 2 experiments are shown ; in each, groups of 6 male $C D$ rats were given 14 consecutive daily doses of 6 CDG by oral gavage. The male rats were paired with virgin females for the latter 7 days and the females were killed 10 days later when the embryos present in their uteri were counted. 
Male rats given a daily dose of 6 CDG $(24 \mathrm{mg} / \mathrm{kg} /$ day) became infertile in 7 days or less and remained sterile as long as treatment was maintained (fig. 2A). When treatment was withdrawn the rats recovered their fertility in 2 weeks or less. By contrast methods which attack spermatogenesis through hormonal treatment (fig. 2B) or chemical means (fig. $2 \mathrm{C}$ ) require longer to take effect and for their action to be reversed.

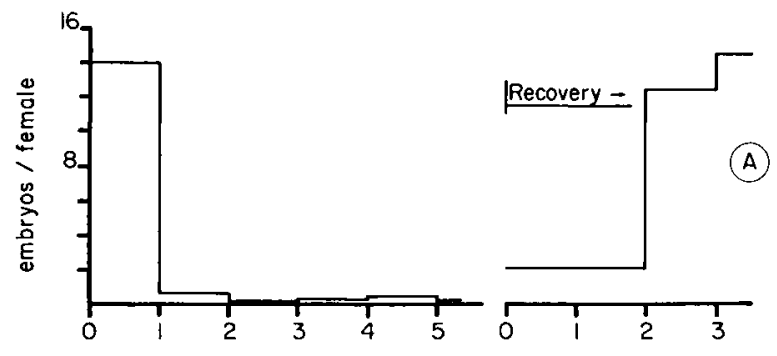

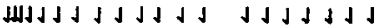
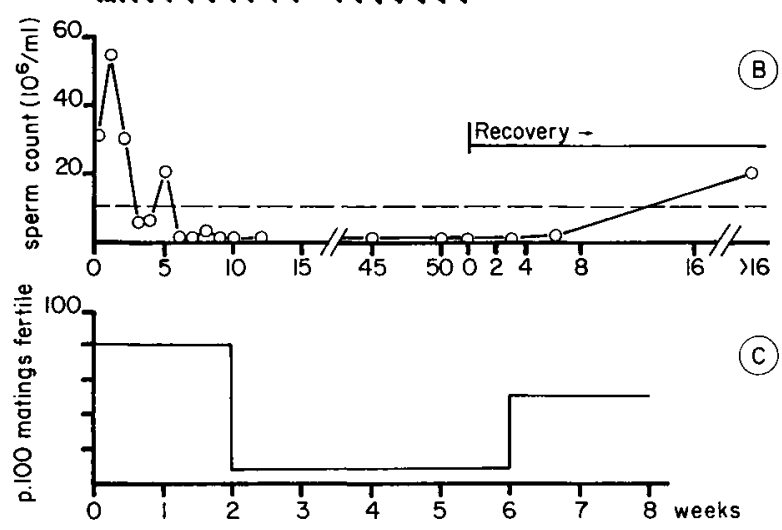

FIG. 2. - (A) A group of 6 mole rats was given 6 CDG (24 kg/day) every day and were paired with a fresh virgin female each week. For the study of recovery a second group of 6 male rats was given 6 CDG (24 $\mathrm{mg} / \mathrm{kg} /$ day) for 14 days. Treatment was withdrawn at the time indicated by 0 . (B) Male volunteers were given testosterone enanthate $(200 \mathrm{mg} \mathrm{i.} \mathrm{m}$.) at the times indicated by the arrows (Steinberger et al., 1978). (C) Male rats were given a single dose of 1-methyl-5-nitroimidazole and were paired with a fresh virgin female at weekly intervals (Patanelli, 1975).

Rats made infertile with 6 CDG continued to produce spermatozoa as rapidly as controls and there was no change in the weights of the testes or accessory organs (table 1) nor in the histological appearance of these tissues (J. R. P. Cabral and W. C. L. Ford, unpublished data). The libido of the males was unimpaired and the offspring borne by females mated by males in which the contraceptive effect was incomplete were normal. 6 CDG $(240 \mathrm{mg} / \mathrm{kg} /$ day $)$ did not reduce the fertility of male mice or hamsters and 6 CDG $(96 \mathrm{mg} / \mathrm{kg} /$ day $)$ had no effect on fertility when given to female rats (W. C. L. Ford, G. L. Takkar and G. M. H. Waites, unpublished results). 
TABLE 1

The number of spermatozoa present in the cauda epididymidis and the weights of the testes and accessory organs in control rats and rats treated with 6-chloro-6-deoxyglucose $(120 \mu \mathrm{mol} / \mathrm{kg} / \mathrm{day})$ or other 6-chloro-6-deoxysugars known to have a similar effect. (Results are means $\pm S E M$ with the number of observations shown in parentheses)

Spermatozoa $\left(\times 10^{8}\right)$ obtained from the cau-

da epididymides of 2 rats .............

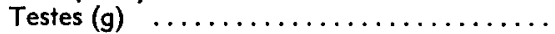

Seminal vesicles (plus coagulating gland) (g)

Ventral prostate $(g) \ldots \ldots \ldots \ldots \ldots \ldots$.

$2.59 \pm 0.14(15)$
$3.15 \pm 0.066(20)$
$1.56 \pm 0.10(20)$
$0.87 \pm 0.072(8)$

\section{Energy metabolism in spermatozoa.}

Spermatozoa from the cauda epididymidis of rats treated with 6 CDG $(24 \mathrm{mg} / \mathrm{kg} /$ day) were unable to oxidise glucose to $\mathrm{CO}_{2}(\mathrm{Fig}$. 3A). These spermatozoa were as motile as controls at zero time (i. e. immediately after they had been removed from the epididymis) but their motility declined rapidly whereas control spermatozoa remained active (fig. 3C). The energy charge (Atkinson and Walton, 1967) of the spermatozoa from rats treated with 6 CDG $(24 \mathrm{mg} / \mathrm{kg} / \mathrm{day})$ was in the control range at zero time but declined to become significantly less than the controls after $40 \mathrm{~min}$ (fig. 3B). $2 \mathrm{mM}$-D glucose was the only substrate supplied in the incubation medium used in these experiments. The infertile spermatozoa were unable to produce sufficient energy to remain motile (or fertile) from this substrate.
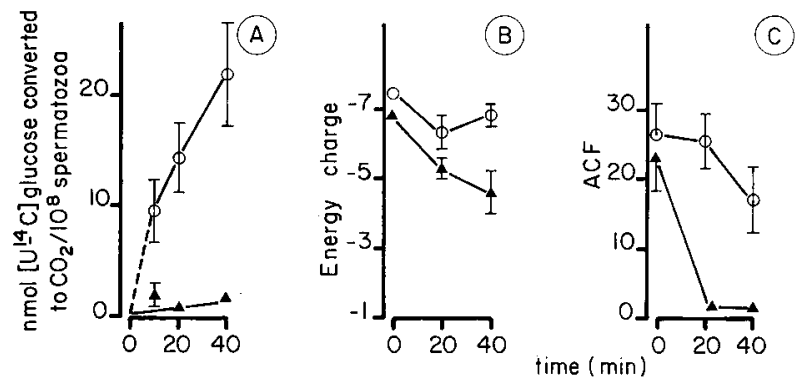

FIG. 3. - (A) Spermatozoa from the cauda epididymides of rats treated with 6 CDG $(24 \mathrm{mg} / \mathrm{kg} / \mathrm{day})$ for 14 days (4) or controls (o) were incubated with $2 \mathrm{mM}-\underline{D}-\left[U-{ }^{14} \mathrm{C}\right]$ glucose in a shaking water bath at $34{ }^{\circ} \mathrm{C}$. Reaction was stopped by the addition of perchloric acid and ${ }^{14} \mathrm{CO}_{2}$ was trapped in hyamine hydroxide. There were 6 rats in each group and spermatozoa from 2 rats were pooled for each series of incubations, results are shown as mean \pm SEM. (B). Spermatozoo from rats given 6 CDG $(24 \mathrm{mg} / \mathrm{kg} /$ day for 14 days) (4) or controls (o) were flushed from the cauda epididymides with buffer containing $2 \mathrm{mM}$ - glucose. The volume was made up to $2.5 \mathrm{ml}$ and a $0.70 \mathrm{ml}$ sample was removed and mixed with $0.35 \mathrm{ml}$ perchloric acid $(10 \mathrm{p} .100 \mathrm{w} / \mathrm{v})$. Further such samples were removed after 20 and 40 min incubation at $34^{\circ} \mathrm{C}$ in a shaking water bath. Denatured protein was removed by centrifugation and the supernatant subsequently neutralised. Adenine nucleotides were assayed as described by Williamson and Corkey (1969). Each point is the mean \pm SEM of 6 rats. (C) $5 \mu \mathrm{l}$ samples were removed from the incubations described for 3 (B) and sperm motility was measured by the procedure of Dott and Foster (1979). Each point is the mean \pm SEM of 6 rats. 
The specific activity ( $\mu \mathrm{mol}$ substrate converted/mg protein/min) of glyceraldehyde 3-phosphate dehydrogenase [E. C. 1.2.1.12] was much less in spermatozoa from rats treated with 6 CDG $(24 \mathrm{mg} / \mathrm{kg} /$ day) than in those from controls (fig. $4 \mathrm{~A})$. There was also a large decrease in the specific activity of triosephosphate isomerase [E.C. 5.3.1.1] and small but statistically significant decreases in hexokinase [E.C. 2.7.1.1] and lactate dehydrogenase [E.C.1.1.1.27]. After $40 \mathrm{~min}$ incubation with $2 \mathrm{mM}$ D-glucose the concentrations of D-glycerate 3-phosphate and phosphoenolpyruvate were less in spermatozoa from rats treated with 6 CDG $(24 \mathrm{mg} / \mathrm{kg} /$ day $)$ than in control spermatozoa but the concentration of fructose 1,6-bisphosphate was increased (fig. 4B). Thus the principal impediment to flux through the pathway could be at the glyceraldehyde 3-phosphate dehydrogenase reaction, but the decreases observed in the concentrations of glucose 6-phosphate and the triosephosphates imply that other factors are involved.

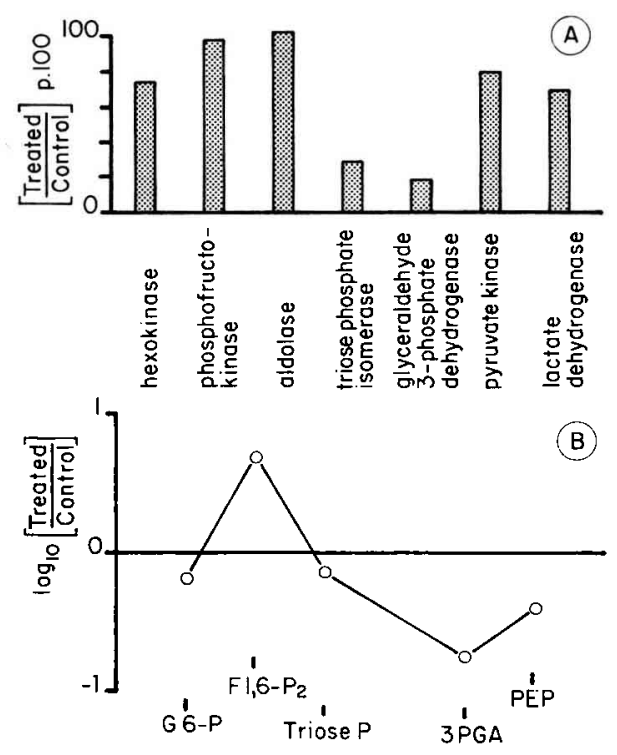

FIG. 4. - (A) Spermatozoa from the couda epididymides of rats treated with 6 CDG $(24 \mathrm{mg} / \mathrm{kg} /$ day for 14 days) and from controls were mixed with aqueous glycerol $(50$ p. $100 \mathrm{w} / \mathrm{v})$ and frozen and stored under liquid nifrogen. After thawing the spermatozoa were lysed by mixing the slurry with $100-200$ vol. $10 \mathrm{mM}$-potassium phosphate buffer $\mathrm{pH} 7.4$. The enzymes were assayed in portions of this suspension (Bergemeyer, 1974). The ratios were calculated from the means of 6 treated and 6 control rats. (B) The metabolites were measured in portions of the perchloric acid extract from the incubations described in fig. 3 (B) (Maitra and Estabrook, 1964). The ratios were calculated from the means of 3 treated and 3 control rats except for glucose 6-phosphate for which 6 rats in each group were measured.

Spermatozoa from rats treated with 6 CDG $(24 \mathrm{mg} / \mathrm{kg} /$ day $)$ oxidized lactate or pyruvate as rapidly as control spermatozoa (fig. $5 \mathrm{~A}$ ) and could sustain motility and a high energy charge for at least $60 \mathrm{~min}$ when $2 \mathrm{mM}$ L-pyruvate plus $4 \mathrm{mM}$ DL-lactate were supplied as substrates (fig. 5B, C) although as before these parameters declined 
rapidly when $2 \mathrm{mM}$-D glucose was the only substrate present. The inhibition of glucose metabolism might have little effect on the energy supply of spermatozoa in the female tract where lactate and pyruvate are present. Unless sugar metabolism is essential to spermatozoa at some stage 6 CDG (and $\alpha$-chlorohydrin) must produce an additional lesion in spermatozoa.
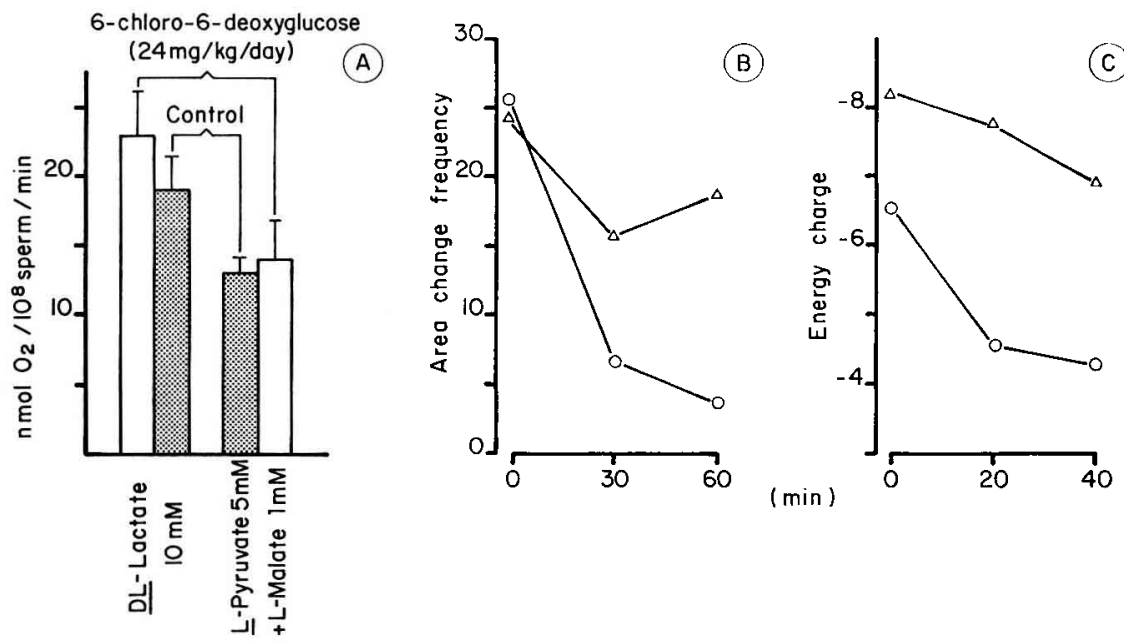

FIG. 5. - (A) Spermatozoa from the cauda epididymides of rats treated with 6 CDG $(24 \mathrm{mg} / \mathrm{kg} / \mathrm{day}$ for 56 days) and from controls were placed in an oxygen electrode maintained at $34^{\circ} \mathrm{C}$. The substrates shown were added once a steady response had been attained. (B) and (C) Spermatozoa were flushed from the cauda epididymides of rats treated with 6 CDG (24 mg/kg/day for 14 days) with buffer containing $2 \mathrm{mM}-\underline{D}$ glucose (0) or $2 \mathrm{mM}-\underline{L}$ pyruvate plus $4 \mathrm{mM}-\underline{D L}$ lactate $(\Delta)$. The suspensions were treated as described for figure 3 (B) abd (C) except that samples were taken after 30 and $60 \mathrm{~min}$.

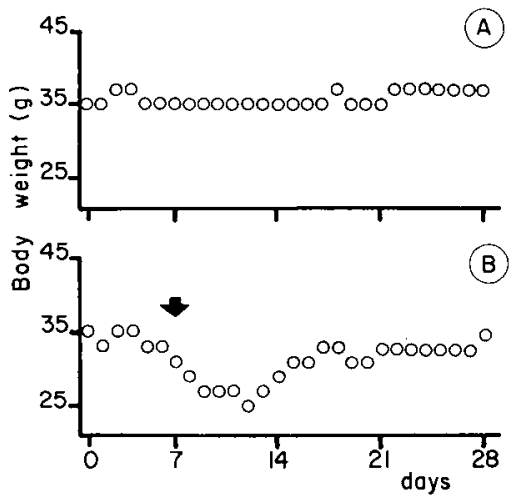

FIG. 6. - Graph (A) shows the body weight of a typical mouse from a group of 8 treated with water $(4 \mathrm{ml} / \mathrm{kg} /$ day). Graph (B) shows a typical individual from a group of 8 treated with 6 CDG $(480 \mathrm{mg} / \mathrm{kg} / \mathrm{day})$. Treatment was withdrawn when symptoms of paralysis first appeared (shown by the arrow). 
The effect of high doses of 6-chloro-6-deoxyglucose in the rat.

Fiffy percent of rats given a single large dose of 6 CDG $(250 \mathrm{mg} / \mathrm{kg})$ developed spermatocoeles which were identical in appearance to those produced by $\alpha$-chlorohydrin (Ericsson, 1970 ; Hoffer et al., 1973). The lesions occurred in the efferent ducts, the coni vasculosi and zone 1 of the caput epididymidis (Reid and Cleland, 1957) with equal frequency.

When 6 male rats were given 6 CDG $(240 \mathrm{mg} / \mathrm{kg} /$ day for 28 days) they all developed spermatocoeles but otherwise appeared in good condition at the end of the experiment. Despite an extensive programme of biochemical, haematological and histological tests the spermatocoeles were the only difference found between these rats and the control group apart from a slight reduction in growth and a small decrease in the concentration of triglyceride in blood serum. The same dose of 6 CDG had no effect on a group of 6 female rats.

The effect of high doses of 6-chloro-6-deoxyglucose in the mouse.

Thirteen male mice from a total of 24 given 6 CDG $(480 \mathrm{mg} / \mathrm{kg} / \mathrm{day})$ developed paralysis of the hind limbs. If treatment was withdrawn soon afterwards the mice appeared to recover and regained their original weight (fig. 6) but if treatment was continued the paralysis worsened and the entire hindquarters became affected. In this state urine was retained in the bladder which became greatly distended and the back became humped. Death occurred a short time later. All the mice became affected at about the same time $(7.8 \pm 0.3$ days $)$ and mice which survived beyond this period remained in good health during at least 20 days further treatment. All the treated mice remained fertile as long as they were physically capable of mating. There was no change in the weights or histological appearance of tissues outside the nervous system.

\section{Conclusions.}

The inhibition of glycolysis in spermatozoa from rats treated with 6 CDG remains the most likely explanation of why they become infertile. However since such spermatozoa can obtain energy from other substrates the effect may be more far reaching than a simple restriction in the regeneration of ATP.

The side effects of 6-chloro-6-deoxyglucose are similar to those of $\alpha$-chlorohydrin and it is still too toxic to be acceptable as a human contraceptive. Nevertheless the rapid action and absence of side effects at the contraceptive dose make it worthwhile to search for less toxic compounds with a similar effect on spermatozoa.

6-Chloro-6-deoxyglucose has no effect on spermatozoa from untreated rats in vitro and is extensively metabolised in vivo (W. C. L. Ford and Anne Harrison, unpublished results) and it is probable that both the antifertility effect and the toxic effects are caused by metabolites rather than the parent compound. The metabolite responsible for the antifertility effect may have a highly selective attack on spermatozoa and could itself or as a suitable derivative provide an ideal male contraceptive.

Symposium on «Male accessory glands».

3rd French-British Meeting of the Societies for the Study of Fertility and Sterility,

Gaillon, 14-16 December 1979. 
Acknowledgements. - We acknowledge the skilled technical assistance of Miss Anne Harrison who made many of the biochemical measurements and Miss Pam Rummings who dosed the animals. This work was supported by grants No. 75311 and 77127 from the World Health Organization.

\section{Résumé}

1. Le 6-chloro-6-désoxyglucose $(24 \mathrm{mg} / \mathrm{kg} / \mathrm{jour})$ produit une inhibition rapide ef réversible de la fertilité chez le rat mâle, mais des doses élevées $(200 \mathrm{mg} / \mathrm{kg} / \mathrm{jour})$ provoquent des spermatocoeles. Chez la souris, de fortes doses répétées $(480 \mathrm{mg} / \mathrm{kg} / \mathrm{jour})$ entraînent la paralysie de l'arrière-train mais sont sans effet propre sur la fertilité.

2. Les spermatozoïdes de rats traités avec du 6-chloro-6-désoxyglucose $(24 \mathrm{mg} / \mathrm{kg} / \mathrm{jour})$ sont incapables de métaboliser le glucose ; ils sont rapidement épuisés lorsque le glucose est le seul substrat qui leur est donné. La glycolyse est inhibée au niveau de la rédaction de la glyceraldehyde-3-phosphate déshydrogénase. Ces spermatozoïdes peuvent obtenir de l'énergie en oxydant du pyruvate ou du lactate.

3. Les effets secondaires du 6-chloro-6-désoxyglucose empêchent son utilisation chez I'homme mais une meilleure connaissance de son mode d'action peut conduire au développement de composés ayant une meilleure sélectivité d'atteinte des spermatozoïdes.

\section{References}

ALBERT A., 1973. Selective toxicity (5th ed.), Chapman and Hall, London.

ATKINSON D. E., WALTON G. M., 1967. Adenosine triphosphate conservation in metabolic regulation .J. biol. Chem., 242, 3239-3241.

BERGEMEYER H. V., 1974. Methods of enzymatic analysis (2nd English ed.), Acad. Press, New York, San Francisco, London.

BROOKS D. E., HAMILTON D. W. MALLEK A. H., 1974. Carnitine and glycerol phosphorylcholine in the reproductive tract of the male rat. J. Reprod. Fert., 36, 141-160.

CASILLAS E. R., ERICKSON B. J., 1975. The role of carnitine in spermatozoan metabolism : Substrate induced elevations in the acetylation state of carnitine and coenzyme $A$ in bovine and monkey, spermatozoa. Biol. Reprod., 12, 275-283.

CLAUSEN J., 1969. Lactate dehydrogenase isoenzymes of sperm cells and testes. Biochem. J., 111, 207-218.

DOTT H. M., FOSTER G. C. A., 1979. The estimation of sperm motility in semen, on a membrane slide by measuring the area change frequency with an image averaging computer. J. Reprod. Fert., 55, 161-166.

ERICSSON R. J., 1970. Male antifertility compounds. U-5897 as a rat chemosterilant. J. Reprod. Fert., 22, 213-222.

EWING L. L., ROBHAIRE B., 1978. Endogenous antispermatogenic agents. Prospects for male contraception. Ann. Rev. Pharmacol. Toxicol. 18, 167-187.

FORD W. C. L., 1980. The contraceptive effect of 6-chloro-6-deoxysugars in the male. in CUNNINGHAM G. R. SCHILL W. B., HAFEZ E. S. E., Regulation of male fertility, Martinus Nijhoff Publ., The Hague, The Netherlands (in press)

FORD W. C. L., WAITES G. M. H., 1978a. A reversible contraceptive action of some 6-chloro-6deoxysugars in the male rat. J. Reprod. Fert., 52, 153-157.

FORD W. C. L., WAITES G. M. H., 1978b. Chlorinated sugars : A biochemical approach to the control of male fertility. Int. J. Androl. Suppl. 2, 541-564.

HEARN J. R., 1978. Antifertility effects of 6-chloro-6-deoxyglucose (6CDG) on male marmoset monkeys. Soc. for the Study of Fertility Annu. Conf., 10-14th July, 1978, Cambridge (Published by title only).

HEITFELD F., MCRAE G., VICKERY B., 1979. Antifertility effects of 6-chloro-6-deoxyglucose in the male rat. Contraception, 19, 543-556. 
HOFFER A. P., HAMILTON D. W., FAWCETT, D. W., 1973. The ultrastructural pathology of the rat epididymis after administration of $\alpha$-chlorohydrin (U-5877). Anat. Rec., 175, 203-230.

HUTCHINSON J. S. M., POULSON C. J. C., 1977. Hormonal contraception in men. Biblio. Reprod. 29, 181-186 and 267-271.

JACKSON H., ROONEY F. R., FITZPATRICK R. W., GIBSON K. H., 1977. Characterisation and antifertility activity in rats of $\mathrm{S}(+) \alpha$-chlorohydrin. Chem. Biol. Inferactions, 17, 117-120.

JONES A. R., 1978. The antifertility actions of $\alpha$-chlorohydrin in the male. Life Sci., 23, 1625-1646.

KALLA N. R., 1976. Chlorohydrins and male fertility regulation. Biblio. Reprod. 28, 261-264 and 349-351.

KATZEN H. M., 1967. The multiple forms of mammalian hexokinase and their significance to the action of insulin. Adv. Enz, Reg., 5, 335-356.

MAITRA P. K., ESTABROOK R. W., 1964. Fluorimetric analysis of glycolytic intermediates. Anal. Biochem., 7, 472-484.

PATANELLI D. J., 1975. Suppression of fertility in the male, 245-258. in HAMILTON D. W., GREEP R. O., Handbook of Physiology, Sect. 7, Vol. 5, Male Reproductive System, Am. Physiol. Soc., Washington.

PAUL R., WILLIAMS R. P., COHEN E., 1974. Structure-activity studies with chlorohydrins as orally active male antifertility agents. Contraception, 9, 951-957.

PHILLIPS D. M., 1975. Mammalian sperm structure, 405-420. In GREEP R. O., ASTWOOD E. B., Handbook of Physiology, Sect. 7, Vol. 5, Male Reproductive System, Am. Physiol. Soc., Washington.

REID B. L., CLELAND K. W., 1957. The structure and function of the epididymis. 1. The histology of the rat epididymis. Austr. J. Zool., 5, 224-252.

STEINBERGER E., SMITH K. D., RODRIQUEZ-RIGAN L. J., 1978, Suppression and recovery of sperm production in men treated with testosterone enanthate for one year. A study of a possible reversible male contraceptive. Int. J. Androl. Suppl. 2, 748-759.

SWEELEY C. C., BENTLEY R., MAKITA M., WELLS W. W., 1963. G. I. c. of trimethylsilyl derivatives of sugars and related substances. J. am. Chem. Soc., 85, 2497-2507.

WILLIAMSON J. R., CORKEY B. E., 1969. Assays of intermediates of the citric acid cycle and related compounds by fluorimetric enzymes methods. In LOWENSTEIN J. M., Methods in enzymology, Vol. 13, 434-513. Acad. Press, New York. 